\title{
Lateral duodenal wall perforation due to plastic biliary stent migration: a case series of endoscopic closure
}

\section{다(1)(우우}

\author{
Authors \\ Institutions \\ 1 Université Libre de Bruxelles, Campus Erasme, \\ Gastroenterology, Brussels, Belgium \\ 2 Université Libre de Bruxelles, Campus Erasme, \\ Radiology, Brussels, Belgium
}

Marc-Andre Bureau ${ }^{1}$, Paraskevas Gkolfakis ${ }^{1}$, Daniel Blero ${ }^{1}$, Martina Pezzullo ${ }^{2}$, Jacques Devière ${ }^{1}$, Arnaud Lemmers ${ }^{1}$

submitted 14.8 .2019

accepted after revision 28.10.2019

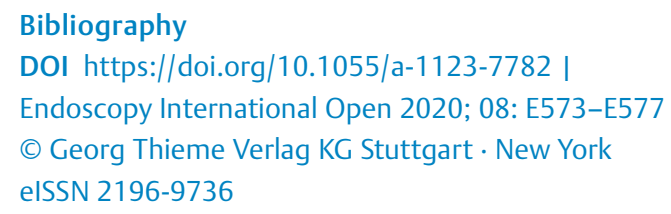

Corresponding author

Marc-Andre Bureau, Université Libre de Bruxelles - Campus

Erasme - Gastroenterology, Route de Lennik 808 Bruxelles

1070, Belgium

Fax: +3225554594

Marc-Andre.Bureau@USherbrooke.ca

\begin{abstract}
Background and study aims Lateral duodenal wall perforation by a migrated stent is a potential complication of biliary stenting. By systematic database revision, we identified a series of six patients with lateral duodenal wall perforation caused by a displaced plastic biliary stent that were treated with over-the-scope clip (OTSC) between January 1, 2014 and March 31, 2019. In this series, most cases were related to stenting of benign strictures with single or double stenting and with the use of stents longer than $12 \mathrm{~cm}$. OTSC permitted perforation closure in all cases. Most patients had an excellent outcome and did not need any subsequent intervention. However, one patient, who presented with a more severe pneumoretroperitoneum on computed tomography scan, required laparotomy with peritoneal lavage and eventually died due to this complication. We conclude that endoscopic treatment of these perforations with OTSC could be an effective alternative to surgery in selected patients.
\end{abstract}

\section{Introduction}

Plastic stent migration after endoscopic biliary drainage can happen in approximately $5 \%$ of cases and may very rarely lead to lateral duodenal wall perforation [1,2]. Treatment options when this occurs include endoscopic treatment with throughthe-scope (TTS) clips or over-the-scope clips (OTSC) and surgical repair $[3,4]$. The latest option is recommended when perforation is not diagnosed immediately $(>12 \mathrm{~h}$ ) and when there is contrast extravasation or intra-abdominal fluid collection [4]. Successful endoscopic treatment of these perforations using OTSC, even when it was diagnosed more than 12 hours after the initial insult, was reported in a few case reports [57], but data about efficacy of such treatment in this indication remain sparse. We aimed to review and describe the clinical characteristics and outcomes of all cases of lateral duodenal wall perforation due to migrated biliary stent that were endoscopically treated using OTSC in a tertiary referral center over 50 months.

\section{Case reports}

Cases were obtained by systematic review of the prospective database including all endoscopic retrograde cholangiopancreatographies (ERCPs) performed in our center from January 1, 2014 to March 31, 2019 identifying all cases having duodenal perforation secondary to biliary plastic stents displacement. Individual data of the screened cases including demographics, stenting indication, migrated stents' characteristics, time from stent placement to perforation, time from perforation diagnosis to endoscopic treatment and finally immediate and 28-day treatment outcome were extracted.

Over this period, out of 696 ERCPs in which plastic stents were placed, 6 cases $(0.8 \%)$ of lateral duodenal wall perforation ( Fig. 1) caused by plastic biliary stent displacement were identified. Their main characteristics are presented in $>$ Table 1. In most cases $(5 / 6)$ the diagnosis of perforation was established early after the stent placement ( $<5$ days) but none was made in less than 12 hours. All five patients developed abdominal pain and fever and the diagnosis was made based on the computed tomography (CT) imaging. The other patient had no symptoms 

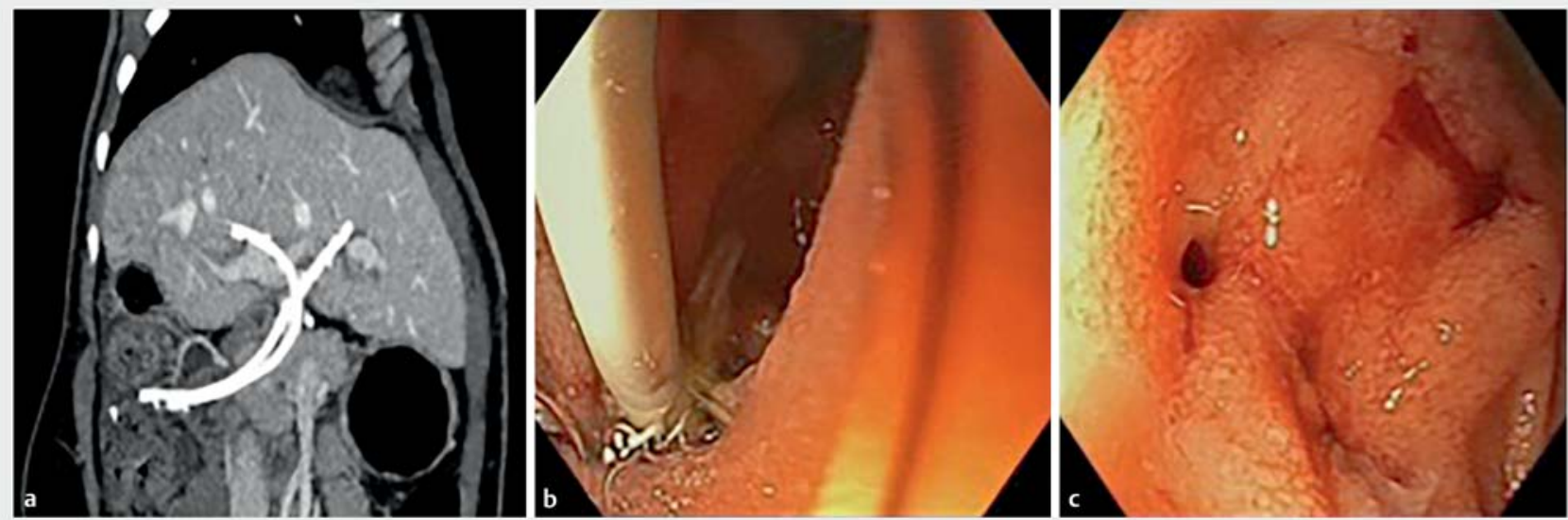

- Fig. 1 Radiologic and endoscopic pictures from patient 6. a CT-scan showing migration through the duodenal wall of the stent placed in the left hepatic ducts. $\mathbf{b}$ Endoscopic image of the double flap plastic stent perforating the duodenum. $\mathbf{c}$ Lateral duodenal wall perforation as seen after stent removal.

and a stent perforating the duodenal wall was found during an elective ERCP planned for stents replacement 90 days after the initial one.

Regarding indication for biliary stenting, five patients were treated for benign biliary stricture (BBS) (three after liver transplantation, one secondary to multiple common bile duct stones and one due to external compression after hepatic artery embolization). The remaining patient had a biliary leak after undergoing right hepatectomy for colorectal cancer metastasis.

Certain similarities are evident regarding the technical characteristics of the stents used among the reported cases ( $\triangleright \mathrm{Ta}$ ble 1$)$. First, for most of the patients $(5 / 6)$, biliary stenting was done with either one or two stents (one and four patients, respectively). Inversely, only one patient had multiple $(\geq 3)$ stents in place. Double flaps plastic stents were used in four of them and in one patient a single preformed sigmoid-shaped plastic stent was used.

In all cases the longest stent was the culprit and in five of six patients it migrated from the left intra-hepatic bile ducts. The length of the perforating stents ranged from $12 \mathrm{~cm}$ to $18 \mathrm{~cm}$. Moreover, two patients with BBS had a history of previous stenting achieving a higher calibration diameter than what was applied at the last examination. More specifically, Patient 3 had a previous maximum calibration of $18.5 \mathrm{Fr}$ while the total diameter of stents in his last ERCP was of $10 \mathrm{Fr}$ and Patient 4 had a maximum calibration of $27 \mathrm{Fr}$ while the total diameter of stents in his last ERCP was $25.5 \mathrm{Fr}$.

In all cases, the perforating stent was removed with rat tooth forceps after aspiration of digestive fluid, using a therapeutic gastroscope (Olympus GIF-1T160; 1T190) under CO2 insufflation. Immediately thereafter, a T-type teeth 12 -mm over-thescope clip (OTSC) (Ovesco Endoscopy AG, Tübingen, Germany) was placed on the scope and advanced facing the perforation. In every patient, perforation was the size of a single plastic stent (average diameter $3 \mathrm{~mm}$ ) and there was no fibrotic tissue on the edges of the perforation. The sides of the perforation were grasped using the twin grasper (Ovesco Endoscopy AG) and pulled back into the hood with low aspiration before releasing the clip.Duodenal contrast opacification was performed during the same session and, if needed, new biliary stents were inserted afterwards. Broad-spectrum antibiotics were started from the perforation diagnosis and were given for a median time of 9.5 days (3-17 days). A nasogastric tube was inserted in three of six cases at the end of the endoscopic procedure, however, we think that it probably wasn't necessary because immediate contrast injection after OTSC application did not show any residual leak in all procedures. Successful closure of all perforations was confirmed by subsequent imaging modalities ( $\triangleright$ Fig. 2 ).

In five patients no further interventions were needed and outcome at 28 days was excellent for four of them. After initial improvement of his medical condition, one patient (Patient 2) died at day 17 after perforation closure. His death was attributed to septic shock secondary to cholangitis. Further intervention after successful closure of the perforation was needed for only one patient who developed peritonitis secondary to the perforation and required laparotomy and peritoneal lavage. The laparotomy did not show any residual leak at the perforation site but he eventually died of this complication at day 5 post procedure. This patient was an elderly and malnourished man with important comorbid vascular disease. He also had a more worrying CT at time of diagnosis with a large quantity of peritoneal and retroperitoneal air as well as ascites ( $\mathbf{F i g . 3}$ )

\section{Discussion}

As far as we know, our case series is the first to describe in a systematic way the incidence and treatment of duodenal wall perforation by plastic biliary stent migration using OTSC. The main finding is that wall closure was obtained in $100 \%$ of cases, but this is probably not enough in some cases since clinical out- 
- Table 1 Patient characteristics.

\begin{tabular}{|c|c|c|c|c|c|c|c|c|c|}
\hline $\begin{array}{l}\text { Gender, } \\
\text { age }\end{array}$ & $\begin{array}{l}\text { Stenting } \\
\text { indication }\end{array}$ & $\begin{array}{l}\text { Location of } \\
\text { the stricture/ } \\
\text { leak }\end{array}$ & $\begin{array}{l}\text { Days be- } \\
\text { tween stent } \\
\text { placement } \\
\text { and perfora- } \\
\text { tion diagno- } \\
\text { sis }\end{array}$ & $\begin{array}{l}\text { Bray } \\
\text { classifi- } \\
\text { cation } \\
{[1]}\end{array}$ & $\begin{array}{l}\text { Stents } \\
\text { placed/ } \\
\text { migra- } \\
\text { ted } \\
(\mathrm{N} / \mathrm{n})\end{array}$ & $\begin{array}{l}\text { Culprit stent } \\
\text { technical } \\
\text { characteris- } \\
\text { tics }\end{array}$ & $\begin{array}{l}\text { Immediate } \\
\text { outcome }\end{array}$ & $\begin{array}{l}\text { Continued } \\
\text { stenting dur- } \\
\text { ing the same } \\
\text { procedure? }\end{array}$ & $\begin{array}{l}28 \text { days } \\
\text { outcome }\end{array}$ \\
\hline 1. M 75 & $\begin{array}{l}\text { Biliary leak } \\
\text { post hepa- } \\
\text { tectomy }\end{array}$ & Hilar leak & 4 & 1 & $2 / 1$ & $\begin{array}{l}\text { Double flaps } \\
18 \mathrm{~cm} 8.5 \mathrm{Fr}\end{array}$ & $\begin{array}{l}\text { Success at } \\
\text { closure }\end{array}$ & $\begin{array}{l}\text { No } 6 \text { Fr Naso- } \\
\text { biliary cathe- } \\
\text { ter }\end{array}$ & $\begin{array}{l}\text { No further in- } \\
\text { terventions or } \\
\text { complications }\end{array}$ \\
\hline 2. M 61 & $\begin{array}{l}\text { Ischemic cho- } \\
\text { langiopathy } \\
\text { (BBS) and bili- } \\
\text { ary leak post } \\
\text { liver trans- } \\
\text { plantation }\end{array}$ & $\begin{array}{l}\text { Anastomotic } \\
\text { leak }\end{array}$ & 2 & II & $1 / 1$ & $\begin{array}{l}\text { Sigmoid- } \\
\text { shaped } \\
17 \mathrm{~cm} \mathrm{8.5Fr}\end{array}$ & $\begin{array}{l}\text { Success at } \\
\text { closure }\end{array}$ & $\begin{array}{l}\text { No } 6 \text { Fr Naso- } \\
\text { biliary cathe- } \\
\text { ter }\end{array}$ & $\begin{array}{l}\text { No further in- } \\
\text { terventions } \\
\text { but death } 17 \\
\text { days later } \\
\text { (biliary sepsis) }\end{array}$ \\
\hline 3.F 31 & $\begin{array}{l}\text { Choledocho- } \\
\text { lithiasis and } \\
\text { bile duct ste- } \\
\text { nosis (BBS) }\end{array}$ & $\begin{array}{l}\text { Common bile } \\
\text { duct stenosis } \\
\text { at the junc- } \\
\text { tion with cys- } \\
\text { tic duct }\end{array}$ & 4 & IV & $2 / 1$ & $\begin{array}{l}\text { Double flaps } \\
15 \mathrm{~cm} 7 \mathrm{Fr}\end{array}$ & $\begin{array}{l}\text { Success at } \\
\text { closure }\end{array}$ & No & $\begin{array}{l}\text { No further in- } \\
\text { terventions or } \\
\text { complications }\end{array}$ \\
\hline 4. M 52 & $\begin{array}{l}\text { Ischemic cho- } \\
\text { langiopathy } \\
\text { (BBS) }\end{array}$ & $\begin{array}{l}\text { Sub-hilar ste- } \\
\text { nosis }\end{array}$ & 90 & 1 & $3 / 2$ & $\begin{array}{l}\text { Double flaps } \\
12 \mathrm{~cm} \mathrm{8.5Fr}\end{array}$ & $\begin{array}{l}\text { Success at } \\
\text { closure }\end{array}$ & $\begin{array}{l}\text { Yes Double } \\
\text { flaps } \\
12 \mathrm{~cm} 8.5 \mathrm{Fr} \\
\text { RIHD } \\
7 \mathrm{~cm} 10 \mathrm{Fr} \times 2 \\
\text { CBD }\end{array}$ & $\begin{array}{l}\text { No further in- } \\
\text { terventions or } \\
\text { complications }\end{array}$ \\
\hline 5. M 72 & $\begin{array}{l}\text { Bile duct } \\
\text { compression } \\
\text { after hepatic } \\
\text { artery embo- } \\
\text { lization (BBS) }\end{array}$ & $\begin{array}{l}\text { Proximal } \\
\text { common bile } \\
\text { duct stricture }\end{array}$ & 2 & IV & $2 / 1$ & $\begin{array}{l}\text { Double flaps } \\
13 \mathrm{~cm} 8.5 \mathrm{Fr}\end{array}$ & $\begin{array}{l}\text { Success at } \\
\text { closure }\end{array}$ & $\begin{array}{l}\text { Yes Double } \\
\text { flaps } \\
10 \mathrm{~cm} 10 \mathrm{Fr} \\
\text { X2 RIHD } \\
12 \mathrm{~cm} 10 \mathrm{Fr} \\
\text { X1 RIHD }\end{array}$ & $\begin{array}{l}\text { Peritonitis } \\
\text { needing lapa- } \\
\text { rotomy and } \\
\text { death at day } 5 \\
\text { post perfora- } \\
\text { tion }\end{array}$ \\
\hline $6 . F 45$ & $\begin{array}{l}\text { Anastomotic } \\
\text { stenosis post } \\
\text { liver trans- } \\
\text { plantation } \\
\text { (BBS) }\end{array}$ & $\begin{array}{l}\text { Anastomotic } \\
\text { stricture }\end{array}$ & 2 & IV & $2 / 1$ & $\begin{array}{l}\text { Double flaps } \\
12 \mathrm{~cm} 8.5 \mathrm{Fr}\end{array}$ & $\begin{array}{l}\text { Success at } \\
\text { closure }\end{array}$ & $\begin{array}{l}\text { Yes Double } \\
\text { flaps } \\
10 \mathrm{~cm} 10 \mathrm{Fr} \\
\text { RIHD } \\
10 \mathrm{~cm} 10 \mathrm{Fr} \\
\text { LIHD }\end{array}$ & $\begin{array}{l}\text { No further in- } \\
\text { terventions or } \\
\text { complications }\end{array}$ \\
\hline
\end{tabular}

BBS, benign biliary stricture; RIHD, right intrahepatic ducts; LIHD, left intrahepatic ducts; CBD, common bile duct

come obviously depends on the severity of the peritonitis and on the general state of the patient.

In our tertiary referral center, six cases of lateral duodenal wall due to plastic stent displacement were identified over 50 months ( $<1 \%$ of overall ERCPs with biliary plastic stenting; a number similar to the one reported in the literature [2]). Risk factors associated with distal stent migration are not well studied. Potential ones include BBS (against malignant biliary strictures), stent shape as well as single stenting $[8,9]$. These data correlate with our case series. All but one patient with distal migration of a plastic biliary stent had a BBS, and the last one had a postsurgical leak. Of note, half of them were associated to benign stricture due to previous liver transplantation. Moreover, single or double stenting was the most common practice in our cases. Only one patient who presented with distal migration was previously treated with placement of three plastic bili- ary stents. Regarding the length of the stents, all lateral duodenal wall perforations in our cohort were associated with migration of long stents $(\geq 12 \mathrm{~cm})$, often used in the setting of anastomotic stenosis post-orthotopic liver transplantation or of perihilar stenosis. Similarly, longer stents $(\geq 13 \mathrm{~cm})$ were more susceptible to migrate distally in a retrospective study of more than 520 procedures [8]. Temporary placement of multiple plastic stents with repeated interventions and calibration is recommended for the treatment of BBS [10]. Interestingly, in our cohort, two patients had a history of higher maximal calibration of a BBS than the one achieved at the last stenting before perforation. Considering this, we adopted and suggest the policy to always replace biliary stents by at least as many as the number in place before the procedure, especially when the stents are long or bypass the hilum. 

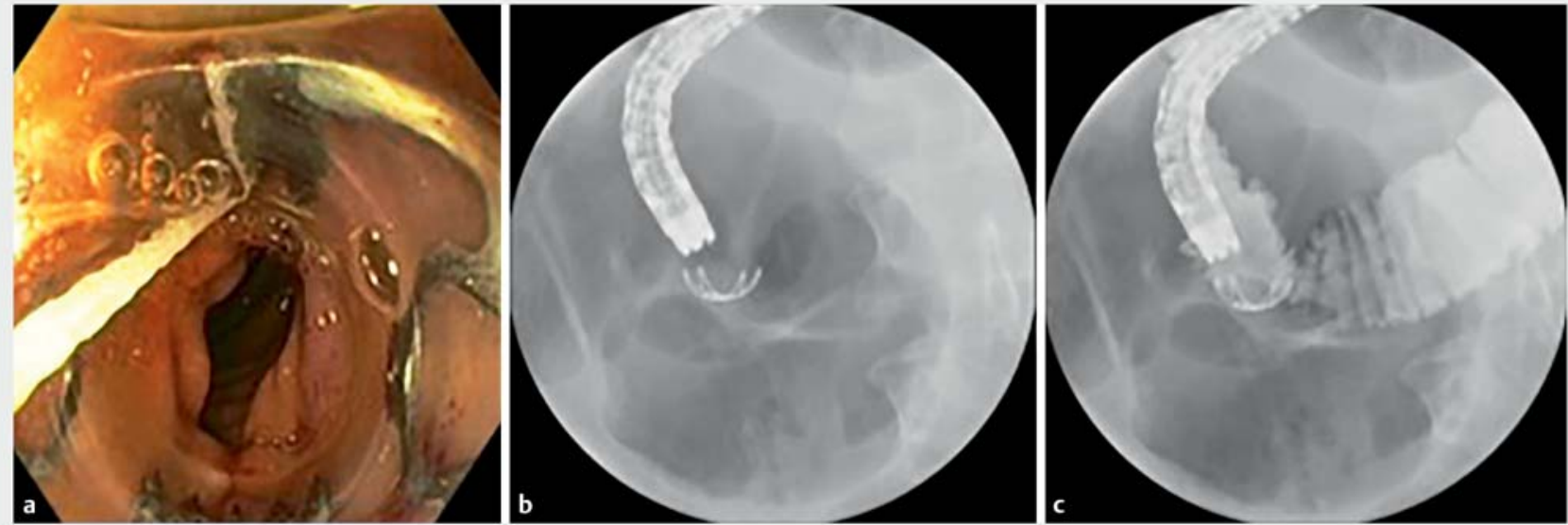

- Fig. 2 Radiologic and endoscopic pictures from patient 2. a Over-the-scope-clip mounted on the tip of the scope before application; b Fluoroscopic image obtained right after placement of OTSC. c Contrast injection showing no leak after the application of OTSC

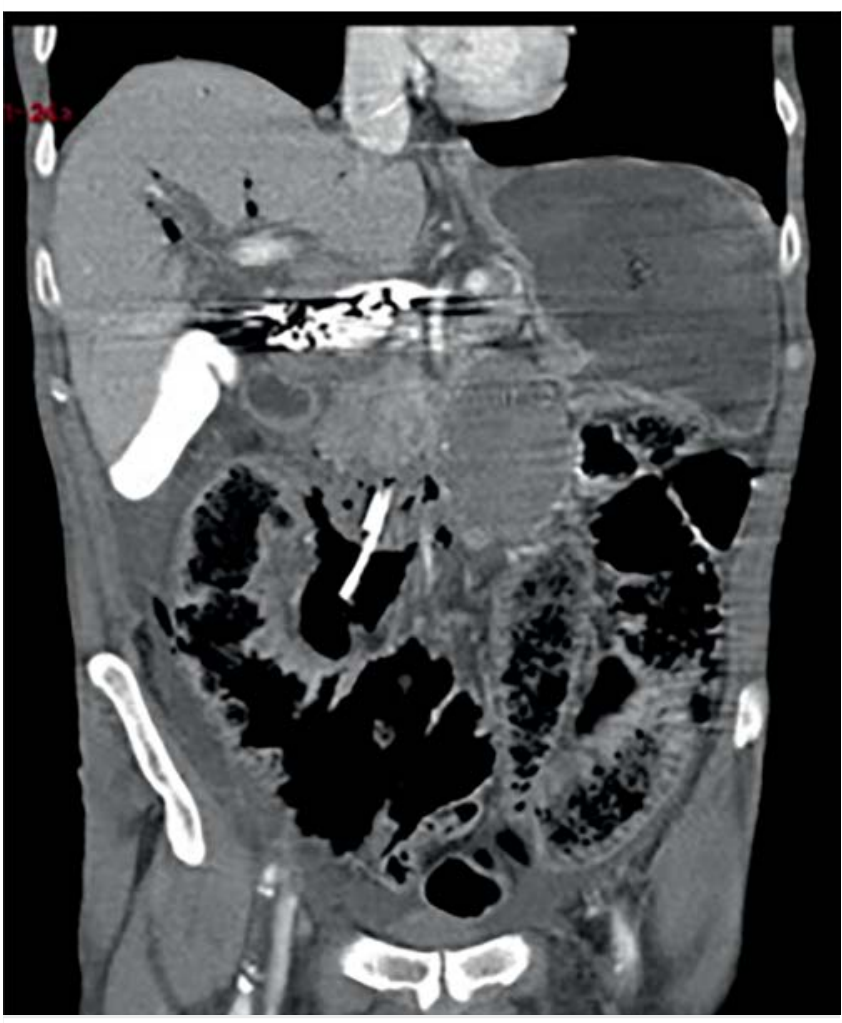

- Fig.3 Computer tomography at the time of the diagnosis showing an important retropneumoperitoneum (Patient 5)

OTSC appears to be an effective treatment with a technical success rate of $100 \%$ in our cohort without any immediate complications. In all patients, follow-up images confirmed that the breach was closed ( $\triangleright \mathbf{F i g} .2$ ). OTSC offers some potential advantages over TTS clips that have also been used to treat these perforations [3]. The main one is that OTSC allows a larger area of tissue to be grasped, a feature potentially beneficial in these stent-induced perforations in which the size at the mucosal lev- el does not necessarily reflect the extent of damage at the layers beyond mucosa. As shown in our case series, OTSC allowed successful sealing of all duodenal wall layers at one time.

Finally, in our series, four of six patients treated with OTSC had a good outcome even if the perforation was diagnosed later than 12 hours after it happened. However, two patients died, including one from complications directly related to the perforation. This highlights the need to select patients who can be treated endoscopically but also to identify early those who could benefit from additional percutaneous drainage or surgery with peritoneal lavage. Patients with a more severe presentation (clinical or radiological) may be the ones that would require a more invasive treatment. Reviewing each patient's CT scan at the time of diagnosis, the patient who did need further intervention (Patient 5) had severe retropneumoperitoneum and significant ascites (Bray type IV perforation) [1]. However, this CT severity index is not perfect since two other patients with Bray type IV perforation had a good clinical evolution.

\section{Conclusion}

In conclusion, lateral duodenal wall perforation by biliary stent migration is a rare complication that was mostly treated surgically. Even if there are obvious limitations in this study because of the retrospective design and the low number of patients, this case series suggests that endoscopic treatment with OTSC can be successful without a subsequent invasive procedure in selected patients and should be incorporated into the treatment algorithm of this complication. More data are needed to identify which patients could benefit from endoscopic treatment and which patients would be better served having more invasive treatment with surgery. 


\section{Acknowledgements}

Dr. Bureau received an educational support grant on therapeutic endoscopy from the Faculté de médecine et des sciences de la santé de l'Université de Sherbrooke. Dr. Gkolfakis received an educational support grant on therapeutic endoscopy from the Hellenic Society of Gastroenterology for providing him an educational support grant on therapeutic endoscopy.

\section{Competing interests}

The authors declare that they have no conflict of interest.

\section{References}

[1] Bray MS, Borgert A], Folkers ME et al. Outcome and management of endoscopic retrograde cholangiopancreatography perforations: A community perspective. Am J Surg 2017; 214: 69-73

[2] Ferm S, Fisher C, Hassam A et al. Primary Endoscopic closure of duodenal perforation secondary to biliary stent migration: a case report and review of the literature. J Investig Med High Impact Case Rep 2018: doi: $10.1177 / 2324709618792031$
[3] Kim SH, Moon JH, Lee YN et al. Endoscopic management of duodenal perforation caused by migrated biliary stents. Endosc Int Open 2019; 07: E792-E795

[4] Paspatis GA, Dumonceau JM, Barthet M et al. Diagnosis and management of iatrogenic endoscopic perforations: European Society of Gastrointestinal Endoscopy (ESGE) Position Statement. Endoscopy 2014; 46: 693-711

[5] Javia SB, Patel R, Singhal S. Endoscopic closure with an over-the-scope clip of a duodenocolonic fistula caused by a migrated biliary stent. Gastrointest Endosc 2016; 83: 845-846; discussion 846-847

[6] Kriss M, Yen R, Fukami N et al. Duodenal perforation secondary to migrated biliary stent in a liver transplant patient: successful endoscopic closure with an over-the-scope clip. Gastrointest Endosc 2015; 81: $1258-1259$

[7] Le Mouel JP, Hakim S, Thiebault H. Duodenal perforation caused by early migration of a biliary plastic stent: closure with over-the-scope clip. Clin Gastroenterol Hepatol 2019; 17: e6-e7

[8] Arhan M, Odemis B, Parlak E et al. Migration of biliary plastic stents: experience of a tertiary center. Surg Endosc 2009; 23: 769-775

[9] Cheruvu S, Kennedy R, Moshenyat $Y$ et al. Biliary stent migration: a brief review of potential complications and possible etiological factors. Am J Ther 2014; 21: e124-129

[10] Dumonceau JM, Tringali A, Papanikolaou IS et al. Endoscopic biliary stenting: indications, choice of stents, and results: European Society of Gastrointestinal Endoscopy (ESGE) Clinical Guideline - Updated October 2017. Endoscopy 2018; 50: 910-930 